Reprod. Nutr. Dévelop., 1987, 27 (5), 897-906.

\title{
Effect of an hypercholesterolemic diet on the level of several serum lipids and apolipoproteins in nine rat strains
}

\author{
Chantal DOUCET, Claudie FLAMENT, C. SAUTIER, D. LEMONNIER \\ with the assistance of Genevievve MATHON and A. N'DIAYE
}

Unité de Recherches sur la Nutrition et l'Alimentation U1 INSERM, Hôpital Bichat, 170, Boulevard Ney 75887 Paris Cedex 18, France.

Summary. To detect the response of different strains of rats to an hypercholesterolemic diet, 9 different strains of male rats were fed successively a control diet (C) containing $20 \%$ casein for 4 weeks, then a high-protein, cholesterol-rich diet $(\mathrm{HC})$ containing $50 \%$ casein and $1.2 \%$ cholesterol for 12 weeks. When the rats were fed the control diet, the highest cholesterolemia was found in the LOU strain and the lowest in the WAG and Brown-Norway (BN) strains. The latter strain had the highest free to esterified cholesterol ratio and showed a marked band in $\beta$ position (LDL) on agarose gel electrophoresis. Administration of the $\mathrm{HC}$ diet induced an increase of cholesterolemia in all the strains except in Fisher (FIS) and LOU. This hypercholesterolemic diet decreased the free to esterified cholesterol ratio only in the BN and FIS strains. On agarose gel, all the strains showed a highly increased band in pre- $\beta$ position (VLDL). On polyacrylamide gel, a single, tight band in HDL position was revealed in the BN strain, while a large band or two bands were seen in the other strains. The percentages of some apoproteins in serum total lipoproteins were determined in rats fed the $\mathrm{HC}$ diet ; the apoprotein E level was inversely correlated to the difference between the cholesterolemia of the rats given the $\mathrm{HC}$ and $\mathrm{C}$ diets $(r=-0.72 ; P<0.05)$. So, the BN rats had the lowest apo $E$ level with the highest cholesterolemia increase due to the $\mathrm{HC}$ diet.

\section{Introduction.}

Rats are known to be particularly resistant to hypercholesterolemia and atherosclerosis. However, this species shows large strain differences when fed a low-cholesterol diet (Tsuji and Suzuki, 1972 ; Müller et al., 1979 ; Nagata et al., 1980 ; Beynen et al., 1983). Moreover, it has been established that different rat strains respond differently when fed a cholesterol-rich diet: some (SpragueDawley, Zucker lean females, Brown-Norway and WE) show greatly increased cholesterolemia and are termed "responders 》; other strains (SHR, S3) are " non-responders " (Van Zutphen and Den Bieman, 1981 ; Terpstra et al., 1982 ; Beynen et al., 1986). This phenomenon, which appears to be under genetic control, has also been observed in other species such as monkeys and rabbits 
(Clarkson et al., 1971 ; Eggen, 1976 ; Shore and Shore, 1976) and humans (Quintao et al., 1971 ; Katan and Beynen, 1983).

In fact, systematic comparative studies in rats are scarce and often limited to serum total cholesterol levels. Little information is available concerning the lipoprotein profiles in different strains of rats and their alterations after feeding a high-cholesterol diet.

The present study was undertaken to see whether any of the characteristics in the 9 strains of rats studied would be different from those in commonly used strains such as Wistar and Sprague-Dawley and more comparable to the characteristics observed in man. With this aim in view, we studied serum total and free cholesterol and phospholipid concentrations and separated lipoproteins by electrophoresis. Rat response to a high-protein, cholesterol-rich diet was determined by testing the same lipid parameters and several apoproteins, chiefly apo E.

\section{Material and methods.}

Animals. - Ten male rats of each strain were used. The 5 inbred strains, obtained from the CNRS (CSEAL, Orléans), were Brown-Norway/Orl (BN), Lewis/Orl (LEW), LOU/Morl (LOU), WAG/Orl (WAG), Fatty/Orl-Fa/? (ZUC). In the latter strain we did not use Zucker obese rats (fa/fa) but only lean animals ; some of these lean rats were heterozygotes $(\mathrm{Fa} / \mathrm{fa})$ and others were homozygotes $(\mathrm{Fa} / \mathrm{Fa})$.

The other 4 strains were furnished by IFFA-CREDO (Les Oncins). Fisher $344 /$ lco (FIS) and Wistar-Furth/Ico (FUR) were inbred strains while the other two, Wistar/Ico : WI (IOPS AF/Han) (WIS) and Sprague-Dawley/lco : OFA-SI (IOPS Caw) (OFA) (OFA: Oncins France A), were not inbred. The above abbreviations have been used in this paper to identify the 9 different strains.

Protocol. - All the strains but one were obtained at 4 weeks of age; the ZUC were obtained at 5 weeks. The rats were housed 5 in a cage in an animal room maintained at $21 \pm 1{ }^{\circ} \mathrm{C}$ with a relative humidity of $60 \pm 5 \%$ and a 12-hour light-dark cycle. The diets were formulated in our laboratory and all the rats were fed ad libitum a control diet $\mathrm{C}(20 \%$ casein) for 4 weeks and then a high-protein (50\% casein), cholesterol-rich (1.2\%) diet HC for 12 weeks (table 1). The latter diet has been described as more hypercholesterolemic than a similar one containing $20 \%$ casein (Terpstra et al., 1982). The rats were weighed weekly and food intake was recorded for $48 \mathrm{~h}$ each week. At the end of each period, blood was obtained from the tail at $2 \mathrm{p}$.m. after a 7-hour fast and allowed to clot for $2 \mathrm{~h}$ at room temperature before centrifugation at $1500 \times \mathrm{g}$ for $20 \mathrm{~min}$ to obtain the serum. The serum was stored at $4{ }^{\circ} \mathrm{C}$ and the assays were carried out over the next $48 \mathrm{~h}$. For apoprotein determination $48 \mathrm{~h}$ after the last blood sample was taken, the rats were fasted in the same conditions as above; they were then lightly anesthetized with diethylether and killed by exsanguination from the abdominal aorta. EDTA and $\mathrm{NaN}_{3}$ were added to the serum $11.0 \mathrm{mg} / \mathrm{ml}$ and $0.2 \mathrm{mg} / \mathrm{ml}$, respectively) and the lipoproteins were promptly separated.

Serum lipid determination. - Total and free cholesterol were measured by the enzymatic method (CHOD-PAP ; kit Boehringer; Mannheim) and phospholipids were determined using an enzymatic colorimetric test (B-test Wako, Biolyon). 
TABLE 1

Composition of the experimental diets $(\mathrm{g} / 100 \mathrm{~g})$.

\begin{tabular}{lcc}
\hline Ingredient & $\begin{array}{c}\text { Control diet } \\
\text { (C) }\end{array}$ & $\begin{array}{c}\text { High-protein, } \\
\text { cholesterol-rich diet } \\
\text { (HC) }\end{array}$ \\
\hline Casein & 20.0 & 50.0 \\
Sucrose & 57.1 & 26.4 \\
Coconut oil & 8.0 & 8.0 \\
Maïze oil & 1.0 & 1.0 \\
Methionine & 0.46 & 0 \\
Cholesterol & 0 & 1.2 \\
Cellulose & 3.7 & 3.7 \\
Yeast & 4.0 & 4.0 \\
Vitamin mixture (1) & 2.2 & 2.2 \\
Mineral mixture (2) & 3.5 & 3.5 \\
\hline
\end{tabular}

(1) Vitamin mixture $(\mathrm{mg} / \mathrm{g})$ : folic acid 0.094 , biotin 0.047 , retinol-cholecalciferol (Roche Rovimix A- $D_{3}$ ) 0.938 , menadione 0.469 , thiamin 0.703 , riboflavin 0.703 , pyridoxin 0.469 , calcium pantothenate 2.344 , niacin 2.344, p-aminobenzoïc acid 14.062, inositol 23.437, vitamin $E$ (Roche Rovimix $E_{50}$ ) 28.124, choline 93.747, vitamin $\mathrm{B}_{12} 0.0023$, excipient (cellulose) 832,474.

(2) Mineral mixture $(\mathrm{mg} / \mathrm{g})$ : La Minière INRA (France) $\mathrm{CaHPO}_{4} 500.0, \mathrm{NaCl} 74.0$, Potassium citrate 220.0, $\mathrm{K}_{2} \mathrm{SO}_{4} 52.0, \mathrm{MgO} 24.0, \mathrm{MnCO}_{3} 3.5$ Iron citrate 6.0, $\mathrm{ZnO} 1.6, \mathrm{CuCO}_{3}, \mathrm{Cu}(\mathrm{OH})_{2} 0.3, \mathrm{KIO}_{3}$ $0.01, \mathrm{Na}_{2} \mathrm{SeO}_{3}, 5 \mathrm{H}_{2} \mathrm{O} 0.01, \mathrm{KCr}\left(\mathrm{SO}_{4}\right)_{2}, 12 \mathrm{H}_{2} \mathrm{O} 0.55$, excipient (sucrose) 118.0 .

Lipoprotein electrophoresis. - Lipoproteins from $2 \mu \mathrm{l}$ of serum were separated by agarose gel electrophoresis using agarose universal electrophoresis film (Corning). After electrophoresis for $35 \mathrm{~min}$ at 60 volts, the film was dried and then stained with Fat Red (Corning). Lipoproteins were also separated by polyacrylamide gel electrophoresis ; $5-\mu l$ samples of serum were prestained with Sudan Black (v/v) and electrophoresed on polyacrylamide gel slabs (lipofilm Sebia) for $1 \mathrm{~h}$ at $8 \mathrm{~mA} / \mathrm{slab}$.

Total lipoprotein preparation. - Total lipoproteins were isolated by centrifugation of serum raised to 1.150 density with $\mathrm{KBr}$, according to the method of Havel et al. (1955). Ultracentrifugation was carried out in a Kontron TGA 50 using a 40.3 rotor. We verified that in the bottom, obtained at $d>1.15$, there were no triglycerides or cholesterol. In a preliminary work, rat serum had been centrifuged by gradient density as described by Camus et al. (1983) ; in the last two fractional parts we found $75 \%$ protein at $1.136<d<1.163$ and $99 \%$ protein at $1.163<$ $\mathrm{d}<1.188$ (unpublished results), while the HDL contained about $50 \%$ protein. These results agree with those obtained by Mahley (1978), who showed that most of rat HDL floats at a density lower than 1.12, and by Oschry and Eisenberg (1982) who observed no $\mathrm{HDL}_{3}$ in rats; Beynen et al. (1984) determined $\mathrm{HDL}_{3}$ containing $0.3 \%$ cholesterol at $d>1.125$. To avoid contamination by serum albumin, the density of the serum $(1 \mathrm{ml})$ was then raised to a solvent density of 1.150 with $\mathrm{KBr}$, and the total lipoproteins were collected without washing after $26 \mathrm{~h}$ at $114000 \times \mathrm{g}$ and $15^{\circ} \mathrm{C}$. Washing and further centrifugation are known to induce high apo $E$ loss. 
The lipoproteins were dialysed at $4{ }^{\circ} \mathrm{C}$ in $0.05 \mathrm{M} \mathrm{NaCl}, \mathrm{pH} 7.4$, containing EDTA $0.04 \mathrm{~g} \%, \mathrm{NaN}_{3} 0.01 \mathrm{~g} \%$, Tris $0.079 \mathrm{~g} \%$. Protein content was measured by the method of Lowry (1951) and after lyophilisation (50 $\mu \mathrm{g}$ of protein) ; the lipoproteins were solubilized without previous delipidation and reduced in $0.5 \%$ SDS, 1 \% 2-mercaptoethanol, $10 \mathrm{mM}$ Tris, $\mathrm{pH} 6.8$.

Apoprotein electrophoresis. - The apoproteins were separated by gradient polyacrylamide slab gel electrophoresis as described by Irwin et al. (1984). The electrophoretic apparatus was made in our laboratory and a linear gradient was realized with 8-15\% acrylamide instead of $10-15 \%$; we used a peristaltic pump and the gels were run for about $16 \mathrm{~h}$ at $9 \mathrm{~mA} / \mathrm{slab}$ and at $4{ }^{\circ} \mathrm{C}$. Molecular weight markers were added to each slab. The gels were stained with Coomassie Blue $R$ 250, destained and scanned in a SEBIA (Cellosystem) densitometer. We did not correct for differences in dye uptake between the apoproteins. The serum concentrations of total apoproteins were estimated by multiplying their distribution percentages in the scanned gels by total apoprotein concentration. While it is recognized that this method is not valid for precise quantification of apoprotein concentration, we found it useful for comparing the different diet effects.

Statistical analysis. - The differences between experimental groups were statistically analysed using the analysis of variance, followed by Duncan's multiple range test (Snedecor and Cochran, 1967) for comparing the multiple groups with one another $(P<0.01)$. The paired $t$-test was used to assess the effect of the $\mathrm{HC}$ diet in a given strain $(P<0.01)$. The correlation coefficient was determined according to Pearson.

\section{Results.}

As expected, body weights differed, depending on the strain, after one month on the control diet. OFA (Sprague-Dawley) rats were the heaviest (285 g) and FUR the lightest $(184 \mathrm{~g})$. The levels of food intake were also different (13 to $18 \mathrm{~g}$ per $24 \mathrm{~h}$ ), but these differences disappeared when body weight was taken into account. Growth and intake were not affected by the cholesterol-rich diet, except in the LOU strain where a slightly higher level of intake was observed per unit of body weight.

$C$ diet. - In rats fed the control diet, large inter-strain differences were observed for total serum cholesterol (fig. 1). LOU rats showed $42 \%$ higher levels than the BN and WAG strains. The BN showed the highest free to esterified cholesterol ratio and the FIS and LOU intermediate ratios (fig. 2). Differences between strains were also observed for serum phospholipids : BN showed the lowest value and WIS the highest (fig. 3).

Photo 1 shows serum agarose gel electrophoresis. In most of the strains two bands were seen, one in pre- $\beta$ (VLDL) and one in the $\alpha$ position (HDL); the latter was very large in ZUC, OFA and LOU rats. However, a well-defined band in $\beta$ (LDL) was seen in the BN. 


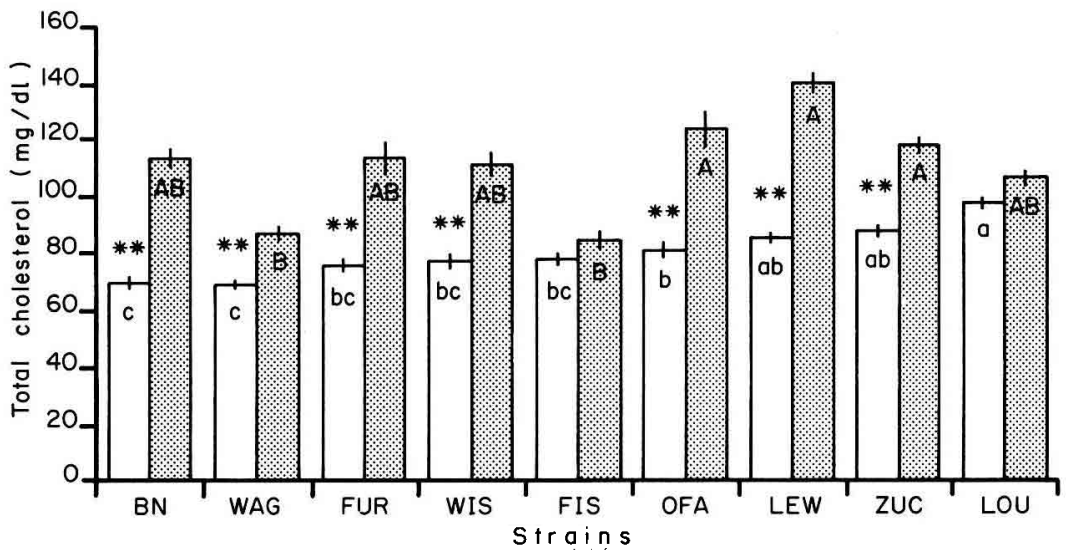

FIG. 1. - Serum total cholesterol levels $(\mathrm{mg} / \mathrm{dl})$ in rats fed $C(\square)$ and HC (웅) diets. Each diagram represents mean values \pm SEM (10 rats/strain). Values with different (small letters : $C$ diet and capital letters : HC diet) are significantly different $(p<0.01)$. ${ }^{* *} \mathrm{C}$ diet versus $\mathrm{HC}$ diet significantly different for each strain $(p<0.01)$.

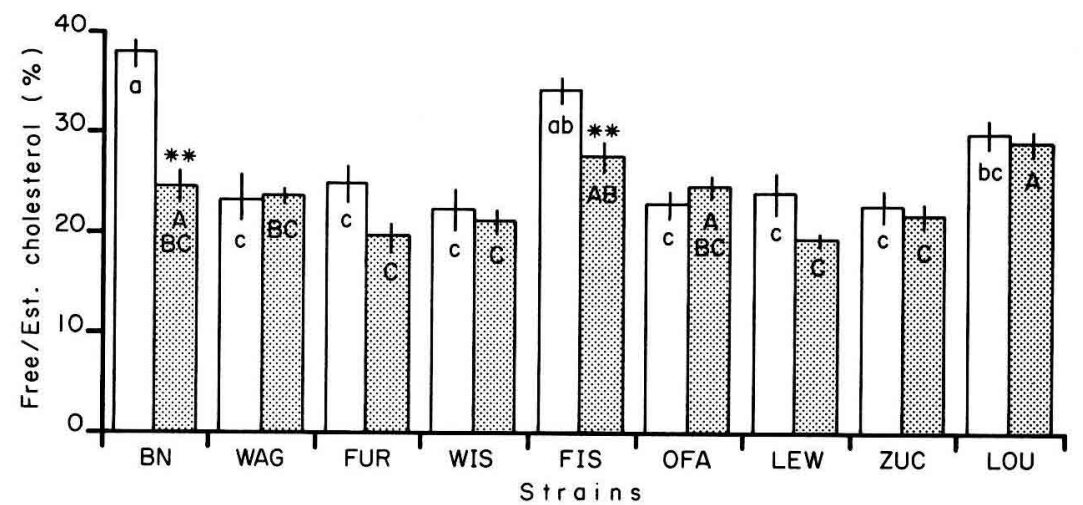

FIG. 2. - Serum free to esterified cholesterol percentages. See legend fig. 1.

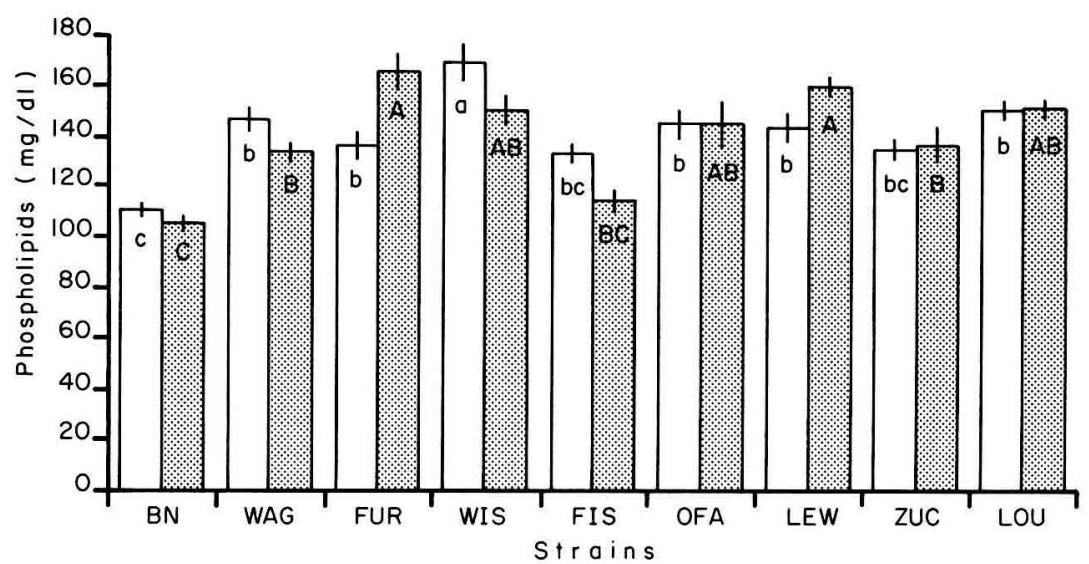

FIG. 3. - Serum phospholipid leve/s (mg/dl). See legend fig. 1. 
HC diet. - Concerning the serum total cholesterol level (fig. 1), FIS and LOU did not respond significantly to the $\mathrm{HC}$ diet. In the other strains, the increases varied between +25 to $50 \%$, except in the LEW and BN rats which were the highest responders (64.0 and $65.1 \%$, respectively). The free to esterified cholesterol ratio was not markedly affected by the experimental diet, except in the FIS and BN strains; it was dramatically decreased in the latter (fig: 2). No change was observed for serum phopholipid levels (fig. 3).

Photo 1 shows that, compared to diet $\mathrm{C}$, feeding the $\mathrm{HC}$ diet markedly increased the pre- $\beta$ band (VLDL) on agarose gel electrophoresis in all strains. In the $B N$ strain fed the $H C$ diet, the $\beta$ band (LDL) disappeared. However, on polyacrylamide gels, realized only when the rats were fed the $\mathrm{HC}$ diet (photo 2 ), this band was lightly apparent in BN, LOU and OFA. This type of electrophoresis showed two bands in HDL position for the WAG, WIS, FIS and LOU and one large band for the other strains, except for the BN where a single, tight band was seen.

The levels of apoproteins AIV, E and Al at the end of $\mathrm{HC}$ diet administration are presented in figure 4. No significant difference was found in the apo AIV levels. Low levels of apo Al were observed in the OFA strain and intermediate levels in the WAG and LOU. The main differences were observed in the apo $E$ levels : rats of the ZUC and BN strains had lower values than the other strains, while the highest values were obtained in the FIS. A negative correlation was found between the mean values for the various strains as to apo $E$ levels and cholesterol response to the $\mathrm{HC}$ diet $(\mathrm{R}=-0.72 ; \mathrm{P}<0.05)$.

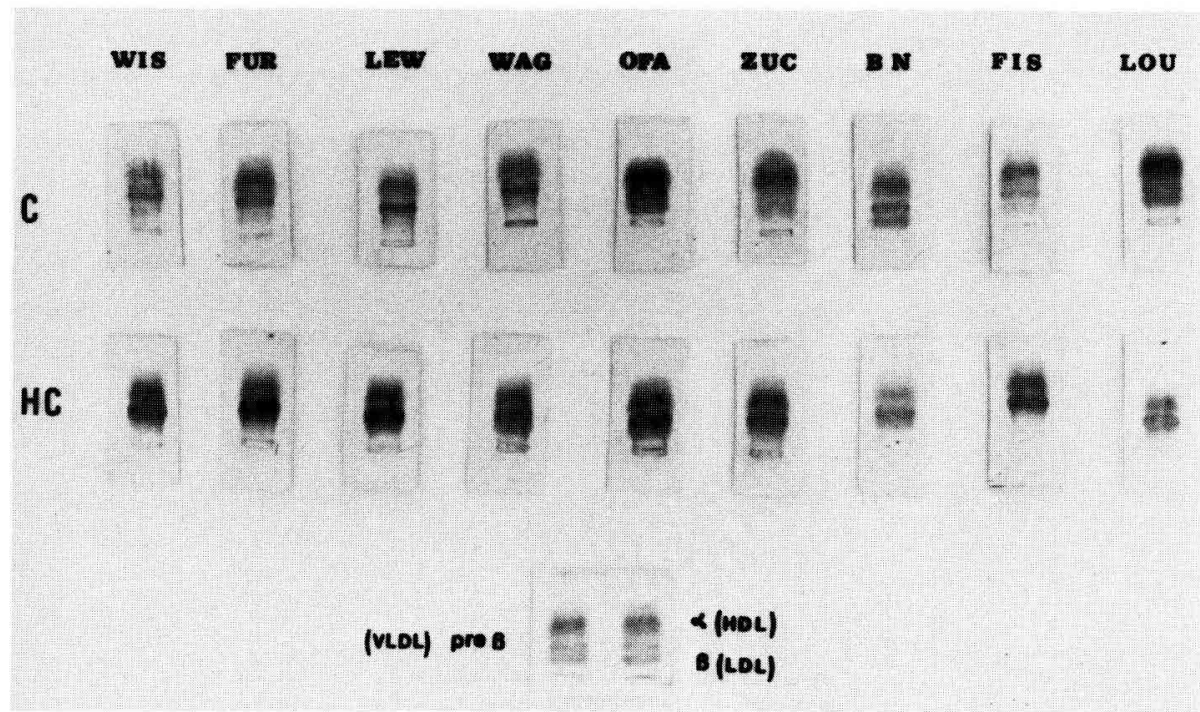

PHOTO 1. - Agarose gel electrophoresis of serum lipoproteins in rats fed $C$ and HC diets. 


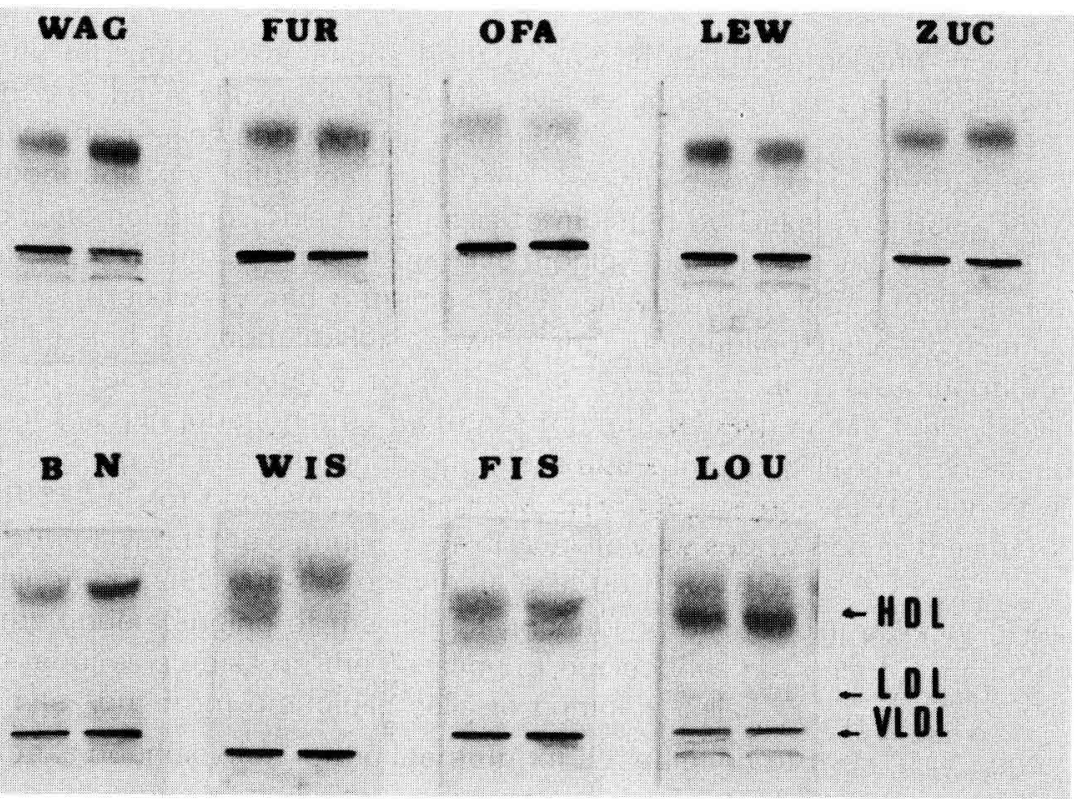

PHOTO 2. - Polyacrylamide gel electrophoresis of serum lipoproteins of 2 representative rats fed $H C$ diet in each strain.
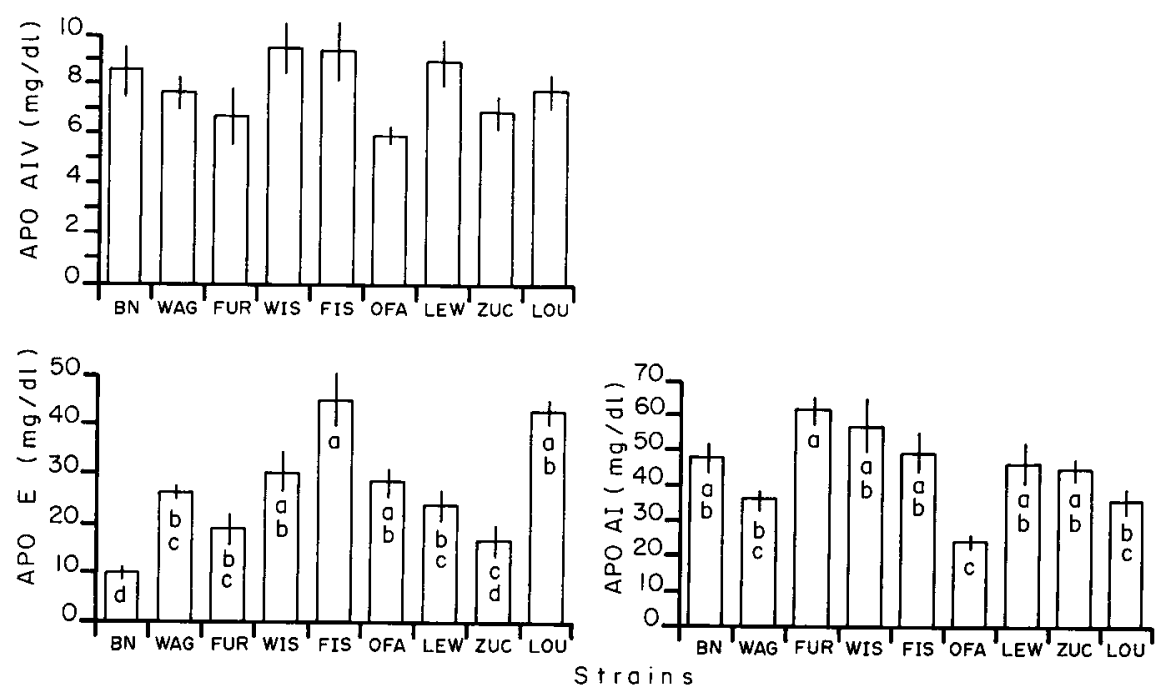

FIG. 4. - Levels of serum apolipoproteins $A N, E, A$ / (mg/dl) in rats fed HC diet. Each diagram represents mean values \pm SEM (4 to 6 rats/strain). Values with different letters are significantly different $(p<0.01)$. 


\section{Discussion.}

Our work clearly indicates considerable divergence between the 9 strains studied as to spontaneous levels of serum cholesterol (diet $\mathrm{C}$ ) and response to the high-cholesterol diet.

Many investigators have studied the response of serum cholesterol to an hypercholesterolemic diet. Van Zutphen and Den Bieman (1981) described the screening of 10 strains of rats fed a standard diet with $2 \%$ cholesterol and $0.5 \%$ cholic acid. The SHR strain was hyporesponsive, whereas Sprague-Dawley and Brown-Norway rats were hyperresponsive. Tsuji and Suzuki (1972) showed that Sprague-Dawley rats were hyperresponders compared to the Wistar strain when fed a cholesterol-rich (1\%) diet. These studies were limited to the analysis of serum total cholesterol levels. Using two strains of male rats (SHR and SpragueDawley), Beynen et al. (1984) found that the response to a diet containing $2 \%$ cholesterol and $0.5 \%$ sodium cholate was higher in the latter strain than in the SHR and was related to an increase in the quantity of VLDL cholesterol.

Our work included 6 more strains besides Sprague-Dawley, Brown-Norway and Wistar. Whatever their basal serum cholesterol levels were, all were responders except for the FIS and LOU rats which showed intermediate and high basal levels, respectively. The BN strain with the lowest basal cholesterolemia responded to the $\mathrm{HC}$ diet by the highest percentage of serum cholesterol increase. So cholesterol response could not be inferred from the basal cholesterol level.

The free to esterified cholesterol (FC/EC) ratio is known to reflect LCAT activity in serum. Also, serum phospholipids are known to play an important role in maintaining lipoprotein structure and may be a source of fatty acids in the esterification of HDL-free cholesterol by LCAT (Glomset, 1968). Two strains (BN and F(S) had a high basal FC/EC ratio, which dramatically decreased when they were fed the HC diet. Their serum phospholipid levels were low and did not change with the diet offered. Nevertheless, the BN strain was a responder and the FIS a non-responder. Cholesterol response did not depend on the FC/EC ratio or on the serum phospholipid level.

After feeding the HC diet, non-responder strains such as LOU and FIS showed a high apo E level. On the contrary, the BN strain, which had as high a cholesterol response as the LEW, also showed the lowest apo E level. It is known that cholesterol feeding drastically alters the distribution of serum cholesterol among the lipoprotein fractions ; the VLDL are greatly enriched in cholesterol and $\beta$ VLDL appears (Lasser et al., 1973). This change was observed on our agarose gel electrophoresis where the pre $\beta$ band was increased in all the strains. The $\beta$ VLDL are rich in apo $E$, but this protein is also the predominant apoprotein of $\mathrm{HDL}_{\mathrm{c}}$. It has been speculated that the $\mathrm{HDL}_{\mathrm{c}}$ transport cholesterol to the liver for excretion (Mahley and Innerarity, 1983). On polyacrylamide gel, the BN strain was the only one to present a single, tight band of HDL. The small quantity of apo $E$ found in this strain could be due to the lack of $\mathrm{HDL}_{c}$. The importance of apo $E$ for lipoprotein uptake by hepatic receptors is known (Mahley and Innerarity, 1983). 
Davis and Malone-McNeal (1985) observed that hepatic apolipoprotein synthesis and secretion were not modified in rats fed a cholesterol-rich $(2 \%)$ diet compared to control rats, although their concentrations of serum apo $E$ decreased $(-40 \%)$. The authors suggest that increased hepatic uptake of apo $E$ might be responsible. Cholesterol response to an hypercholesterolemic diet might be partly related to the activity of hepatic apo $E$ receptors, depending on the rat strain.

The present work confirms the heterogeneity of lipid constants in rat strains fed a cholesterol-rich diet as well as a control diet. Cholesterol response could not be inferred from basal serum cholesterol concentration, the free to esterified cholesterol ratio or the serum phospholipid level. On the other hand, the response was negatively correlated to the serum apo $E$ content in rats fed the hypercholesterolemic diet.

Acknowledgements. - The authors are grateful to the CSEAL-CNRS (45045 Orléans) and IFFA-CREDO (69210 l'Arbresle) which kindly provided the animals.

Résumé. Effet d'un régime hypercholestérolémiant sur le taux de lipides sériques et d'apolipoprotéines dans 9 souches de rats.

Afin de définir la réponse à un régime hypercholestérolémiant, des rats mâles de 9 souches sont soumis successivement à un régime témoin $(\mathrm{C})$, contenant $20 \%$ de caséine, pendant 4 semaines, puis à un régime hypercholestérolémiant $(\mathrm{HC})$, contenant $50 \%$ de caséine et $1,2 \%$ de cholestérol, pendant 12 semaines. Soumis au régime témoin, les LOU ont la cholestérolémie la plus haute, tandis que les WAG et les Brown-Norway (BN) ont la plus basse. Cette dernière souche présente le rapport cholestérol libre/estérifié le plus élevé et une bande nette en position $\beta$ (LDL) est observée sur l'électrophorèse en gel d'agarose. L'administration du régime $H C$ provoque une augmentation du cholestérol sérique de tous les rats, sauf chez les Fisher (FIS) et les LOU. Le rapport cholestérol libre/estérifié est abaissé à ce régime seulement chez les FIS et les BN. Sur gel d'agarose, la bande en position pre $\beta$ est très élargie dans toutes les souches. Sur gel de polyacrylamide, une seule bande fine est visible en position HDL chez les BN, alors qu'une bande plus étalée ou deux bandes apparaissent chez les autres souches. Chez les rats soumis au régime $\mathrm{HC}$, le pourcentage de quelques apoprotéines dans les lipoprotéines sériques totales a été mesuré ; une corrélation inverse est observée entre la concentration en apo E et l'augmentation de la cholestérolémie sous l'action de ce régime $(r=-0,72$; $p<0,05)$. Ainsi les rats $B N$ ont le taux d'apo $E$ le plus bas associé à l'élévation dé cholestérolémie la plus importante.

\section{Références}

BEYNEN A. C., TERPSTRA A. H. M., WEST C. E., Van TINTELEN G., 1983. The concentration of serum cholesterol in rats fed cholesterol-free, low-fat semipurified diets containing either casein or soybean protein. Nutr. Rep. Int., 28, 363-373.

BEYNEN A. C., BOOGAARD A., Van LAACK H. L. J., KATAN M. B., 1984. Cholesterol metabolism in two strains of rats with high or low response of serum cholesterol to a cholesterol rich-diet. J. Nutr., 114, 1640-1651. 
BEYNEN A. C., DANSE L. H. J. C., Van LEEUWEN F. X. R., SPEIJERS G. J. A., 1986. Cholesterol metabolism and liver pathology in inbred strains of rats fed a high-cholesterol, high-cholate diet. Nutr. Rep. Int., 34, 1079-1087.

CAMUS M. C., CHAPMAN M. J., FORGEZ P., LAPLAUD P. M., 1983. Distribution and characterization of the serum lipoprotein and apoproteins in the mouse, Mus musculus. $J$. Lipid Res., 24, 1210-1228.

CLARKSON T. B., LOFLAND H. B., BULLOCK B. C., GOODMAN H. O., 1971. Genetic control of plasma cholesterol. Studies on squirrel monkeys. Arch. Pathol., 92, 37-45.

DAVIS R. A., MALONE-McNEAL M., 1985. Dietary cholesterol does not affect the synthesis of apolipoproteins $B$ and $E$ by rat hepatocytes. Biochem. J., 227, 29-35.

EGGEN D. A., 1976. Cholesterol metabolism in groups of rhesus monkeys with high or low response of serum cholesterol to an atherogenic diet. J. Lipid Res., 17, 663-673.

GLOMSET J. A., 1968. The plasma lecithin : cholesterol acyltransferase reaction. J. Lipid Res., 9, 155-167.

HAVEL R. J., EDER H. A., BRAGDON J. H., 1955. The distribution and chemical composition of ultracentrifugally separated lipoproteins in human serum. J. clin. Invest., 54, 1345-1353.

IRWIN D., O'LOONEY P. A., QUINET E., VAHOUNY G. V., 1984. Application of SDS gradient polyacrylamide slab gel electrophoresis to analysis of apolipoprotein mass and radioactivity of rat lipoproteins. Atherosc/erosis, 53, 163-172.

KATAN M. B., BEYNEN A. C., 1983. Hyper-response to dietary cholesterol in man. Lancet, i, 1213.

LASSER N. I., ROHEIM P. S., EDELSTEIN D., EDER H. A., 1973. Serum lipoproteins of normal and cholesterol-fed rats. J. Lipid Res., 14, 1-8.

LOWRY O. H., ROSEBROUGH N. J., FARR A. L., RANDALL R. J., 1951 . Protein measurement with the folin phenol reagent. J. biol. Chem., 193, 265-275.

MAHLEY R. W., 1978. Alterations in plasma lipoproteins induced by cholesterol feeding in animals including man. In Disturbances in lipid and lipoprotein metabolism, Am. Physiol. Soc., 181-197.

MAHLEY R. W., INNERARITY T. L., 1983. Lipoprotein receptors and cholesterol homeostasis. Biochim. biophys. Acta, 737, 197-222.

MÜLLER K. R., LI J. R., DINH D. M., SUBBIAH M. T. R., 1979. The characteristics and metabolism of a genetically hypercholesterolemic strain of rats (RICO). Biochim. biophys. Acta, 574, 334-343.

NAGATA Y., IMAIZUMI K., SUGANO M., 1980. Effects of soya-bean protein and casein on serum cholesterol levels in rats. Br. J. Nutr., 44, 113-121.

OSCHRY Y., EISENBERG S., 1982. Rat plasma lipoproteins: re-evaluation of a lipoprotein system in an animal devoid of cholesteryl ester transfer activity. J. Lipid Res., 23, 1099-1106.

QUINTAO E., GRUNDY S. M., AHRENS Jr. E. H., 1971. Effects of dietary cholesterol on the regulation of total body cholesterol in man. J. Lipid Res., 12, 233-247.

SHORE B., SHORE V., 1976. Rabbits as a model for the study of hyperlipoproteinemia and atherosclerosis. Adv, exp. Med. Biol., 67, 123-141.

SNEDECOR G. W., COCHRAN W. G., 1967. Statistical methods, 6th ed., 274. Ames lowa, lowa State Univ. Press.

TSUJI K., SUZUKI S., 1972. Influence of strain differences in serum cholesterol levels in rats. Jap. J. Nutr., 30, 235-239.

TERPSTRA A. H. M., Van TINTELEN G., WEST C. E., 1982. The effect of semipurified diets containing different proportions of either casein or soybean protein on the concentration of cholesterol in whole serum lipoproteins in male and female rats. Atherosclerosis, 42, 85-95.

Van ZUTPHEN L. F. M., Den BIEMAN M. G. C. W., 1981. Cholesterol response in inbred strains of rats, "Rattus norvegicus ». J. Nutr., 111, 1833-1838. 